Toyomasa Katagiri • Manabu Futamura

Yusuke Nakamura

\title{
A GIn/Arg polymorphism at codon 349 of the hBUBR1 gene
}

\begin{abstract}
We found a glutamine/arginine polymorphism at codon 349 of the $h B U B R 1$ gene, encoding a protein kinase required for spindle assembly checkpoint function. The observed heterozygosity was estimated to be $45 \%$ in the Japanese population. This polymorphism may be helpful for genetic studies of many cancer types in which chromosomal instability is observed.
\end{abstract}

Key words $\mathrm{SNP} \cdot \mathrm{hBUBR} 1$ gene $\cdot$ checkpoint

\section{Introduction}

$B U B R 1$ is a homologue of the $B U B 1$ gene, (budding uninhibited by benzimidazole 1 ), which encodes a protein kinase required for spindle assembly checkpoint function (Roberts et al. 1994). Recently, mutations of the $h B U B 1$ and $h B U B R 1$ genes were found in human colorectal cancer cells displaying chromosomal instability (Cahill et al. 1998). During screening for possible disease-associated mutations in breast cancer by reverse transcription-polymerase chain reaction-single strand conformation polymorphism (RTPCR-SSCP) analysis, we identified a polymorphism in the $B U B R 1$ gene. Here we describe the Gln/Arg polymorphism of the BUBR1 gene in the Japanese population.

\section{Methods}

\section{RT-PCR-SSCP analysis}

After reverse transcription of total RNA obtained from breast cancer tissue, the BUBR1 cDNA was amplified. The PCR

T. Katagiri $(\bowtie) \cdot$ M. Futamura $\cdot$ Y. Nakamura

Laboratory of Molecular Medicine, Human Genome Center,

Institute of Medical Science, The University of Tokyo, 4-6-1

Shirokanedai, Minato-ku, Tokyo 108-8639, Japan

Tel. +81-3-5449-5372; Fax +81-3-5449-5433

e-mail: yusuke@ims.u-tokyo.ac.jp amplification was performed in a $10-\mu l$ volume. PCR primer sequences used were: 109SPF5 (5'-GAGAATGAGCTGCAAGCAGG-3') and 109SPR5A (5'-ACATGGTGTCATAACTGGCTGT- $3^{\prime}$ ). Cycling conditions were 35 cycles of $94^{\circ} \mathrm{C}$ for $30 \mathrm{~s}, 60^{\circ} \mathrm{C}$ for $30 \mathrm{~s}$, and $72^{\circ} \mathrm{C}$ for $30 \mathrm{~s}$. The resulting PCR products (155bp in length) were electrophoresed in a $6 \%$ polyacrylamide gel containing $0.5 \times \mathrm{TBE}$ and $5 \%$ glycerol at $4^{\circ} \mathrm{C}$. The gels were dried and autoradiographed with intensifying screens. After the purification of PCR products, each sample was subjected to cycle sequencing, using a dye terminator cycle-sequencing kit (Perkin-Elmer, Norwalk, CT, USA) according to the supplier's instructions. The same SSCP primers were used to sequence in both directions. Electrophoresis was carried out using a 377 DNA sequencer (Perkin-Elmer).

Allele-specific oligonucleotide (ASO) analysis

We performed hybridization of allele-specific oligonucleotides to investigate the allelic frequency of codon 349 in a normal control population. PCR products $(3-\mu l)$ were blotted on a Biodyne transfer membrane. Oligonucleotides specific for the Gln allele (5'-ACTGCACAACAGCCA- $\left.3^{\prime}\right)$ and the Arg allele (5'-ACTGCACGACAGCCA-3') were labeled with ${ }^{32} \mathrm{P}$, using 10 units of $\mathrm{T} 4$ polynucleotide kinase. The membranes were hybridized in $6 \times$ sodium saline citrate (SSC), $2 \times$ Denhardt's, $0.5 \%$ sodium dodecyl sulfate (SDS), and $50 \mathrm{mM}$ Tris- $\mathrm{HCl}(\mathrm{pH} 7.5)$ overnight at $42^{\circ} \mathrm{C}$, and washed in $6 \times \mathrm{SSC}$ at $44^{\circ} \mathrm{C}$ for the Gln allele, $46^{\circ} \mathrm{C}$ for the Arg allele, for $5 \mathrm{~min}$. Autoradiography was carried out at $-80^{\circ} \mathrm{C}$.

Allelic frequency

The allelic frequencies were estimated to be $45 \%$, from genotyping of a total of 224 Japanese individuals. The allelic frequencies observed were: Gln allele, 0.31 and Arg allele, 0.69.

Acknowledgements We thank Drs. Toshihiro Tanaka and Hiroyuki Nishimori for their many useful discussions, and Maiko Minami for the excellent technical assistance. 


\section{References}

Cahill DP, Lengauer C, Yu J, Riggins GJ, Willson JKV, Markowitz SD, Kinzler KW, Vogelstein B (1998) Mutations of mitotic checkpoint genes in human cancers. Nature 392: 300-303

Roberts BT, Farr KA, Hoyt MA (1994) The Saccharomyces checkpoint gene BUB1 encodes a novel protein kinase. Mol Cell Biol 14: 8282-8291 